\title{
KORELASI RIBA, ZAKAT DAN SHODAQOH DALAM TEORI BATAS MUHAMMAD SYAHRUR
}

\author{
Ahmad Hamdani \\ E-mail:danielqudsi@gmail.com
}

\begin{abstract}
This article wants to expose the thinking of a controversial Syrian thinker, Prof. Ir. Muhammad Syahrur about the correlation of usury, zakah and shodaqoh. The correlation between these three things to explain one of the forms of boundary theory he found. According to Syahrur usury and zakat contained in the theory of the sixth limit is "the maximum limit (positive) should not be passed and the lower limit (negative) may be passed". This restriction applies to the transition of wealth between people. These two limits consist of the maximum limit that should not be violated, namely usury and the minimum limit of zakat that can be exceeded. This form exceeds the minimum limit of a variety of alms. These two boundaries are in two regions: positive and negative regions, and midpoints in neutral positions denoted by zero. In practice, the positive maximum limit of usury, the neutral limit of interest-free loans and the minimum limit of negatives in the form of zakat and alms. According to Syahrur usury is divided into two forms that are related to borrowing and borrowing and borrowing. Syahrur argues that usury is the same as bank interest and he justifies bank interest as the modern banking mechanism that has been run for this. After describing Syahrur's thoughts, this paper provides some notes on the important points that need to be discussed further.
\end{abstract}

Keywords: usury, zakah, shodaqoh

\section{A. PENDAHULUAN}

Diskursus tentang pembaharuan pemikiran Islam semakin intens dikemukakan oleh para sarjana-sarjana muslim kontemporer. Dan semakin ramai saat sarjana-sarjana muslim mendapat pengaruh yang kuat dari pemikiranpemikiran Barat sebagai konsekwensi dari globalisai dan lebiralisasi. Salah satu topic yang dibicarakan adalah reinterpretasi dan reaktualissasi penafsiran ajaran agama yang dirasa sudah tidak lagi relevan dengan perkembangan jaman. Salah satu topic yang masih menjadi pro-kontra adalah hukum bunga bank yang menjadi basis dari praktek perbankkan. Bunga bank apakah ternasuk riba yang diharamkan dalam Syariat Islam atau tidak? Telah banyak kajian-kajian yang membahas tentang masalah ini dan telah banyak pula fatwa-fatwa yang dikeluarkan oleh para ulama dan lembaga-lembaga fatwa di dunia Islam. Namun nampaknya masalah ini tetap masih actual dan masih menjadi pembahasan oleh para sarjana-sarjana muslim. 
Riba menurut etimologi mempunyai tiga makna, yaitu 1. bertamba (الزيادة) 2. berkembang ( ) 3. berlebihan atau menggelembung. Hal ini sebagaimana firman Allah SWT: QS, Al-Hajj : 5.

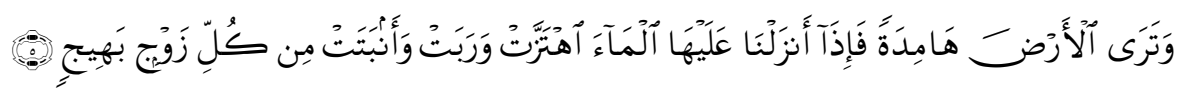

Sedangkan menurut terminology, riba terbagi menjadi dua, yaitu riba al-buyu' dan riba al-qurudl. Riba al-buyu' adalah akad yang terjadi atas penukaran barang tertentu yang tidak diketahui perimbangannya menurut ukuran syara' ketika berakad atau dengan mengakhirkan tukaran kedua belah pihak atau salah satunya. (Al-Kaf, 2013: 21). Riba al-buyu disebut juga riba al-Fadl atau riba al-khofiy atau riba al-Sunnah. (Ilahy, 1986: 27)

Sementara riba al-Qurudl Syeh Muhammad Abduh mendefinisikan: penambahan-penambahan yang diisyratkan oleh orang yang memiliki harta (pemberi pinjaman) kepada orang yang meminjam hartanya (uangnya), karena pengunduran janji pembayaran oleh peminjam dari waktu yang telah ditentukan. Riba al-Qurudl oleh para ulama disebut juga riba al-Nasi'ah atau riba al-jaliy atau riba Al-Qur. an atau riba al-Jahiliyyah. (Ilahy, 1986 : 29)

Riba al-Buyu' disebut riba as-Sunnah karena ketetapan pengharamannya didasarkan pada sunnah nabi, yaitu sabda Rasulullah SAW :

$$
\begin{aligned}
& \text { الذهب بالذهب, والقضة بالفضة, والبر بالبر, والشعير بالشعير, والتمر بالتمر , والملح بالملح, مثلا بمثل, سواء } \\
& \text { بسواء, يدا بيد, فإذا اختلفت هذه الأصناف فبيعوا كيف شئتم اذا كان يدا بيد. (رواه مسلم) }
\end{aligned}
$$

"Emas boleh ditukar dengan emas, perak boleh ditukar dengan perak, gandum boleh ditukar dengan gandum, jelai dengan jelai, kurma dengan kurma, garam dengan garam bila sama jenis dan timbangannya serta kontan. Bila berbeda jenisnya maka boleh tukar menukar sekehendak hati kalian asalkan dengan cara kontan " HR Muslim.

Disebut riba al-Khofiy karena terjadinya riba samar-samar dan ia adalah jalan atau media yang menyampaikan kepada riba jaliy. Riba al-Qurudl disebut riba alQur'an karena riba yang dimaksud dan diharamkan dalam ayat-ayat al-Qur'an adalah riba al-qurudl ini, yaitu riba atau tambahan yang terjadi karena hutang piutang. Disebut juga riba al-Jahiliyyah karena praktek riba al-Qurudl inilah yang dikenal dan dipraktekkan oleh orang-orang arab pada masa jahiliyyah.

Pengharaman dua macam riba diatas adalah telah menjadi kesepakatan ulama. Telah banyak ayat-ayat Al-Qur'an dan hadist-hadist Rasul yang menyebutkan akan masalah ini. Diantaranya firman Allah dalam QS Al-Baqoroh: 275, QS Al-Baqoroh : 276, QS Al-Baqoroh : 278, QS Ali Imron : 130, QS An-Nisa' : 161, QS Ar-Rum: 39 dan lain-lain.

Sedangkan hadist-hadist Rasul diantaranya, sabda Rasulullah SAW :

$$
\text { درهم ربا يأكل الرجل وهو يعلم أشد من ستة وثلاثين زنية رواه احمد والبيهقي }
$$


"Satu dirham uang riba yang dimakan seseorang, sedangkan orang tersebut mengetahuinya, dosa perbuatan tersebut lebih berat daripada dosa tiga puluh enam kali zina". HR Ahmad dan Baihaqi.

$$
\text { قال جابر رضي الله عنه : لعن رسول الله صلى الله عليه وسلم آكل الربا وموكله وكاتبه وشاهديه }
$$

Sahabat Jabir RA. berkata: " Rasulullah melaknat orang yang memakan riba, orang yang mewakilkan, penulisnya, dua saksinya, mereka adalah sama. " (HR. Muslim), dan masih banyak hadist lain yang meneramgkan tentang dilarangnya praktek riba.

\section{B. PEMBAHASAN}

Meskipun sudah sedemikian jelas tentang larangan riba, namun ketika umat Islam harus menghadapi realitas munculnya bank-bank yang berbasis bunga (interest), banyak ulama dan sarjana hukum Islam yang berbeda mensikapinya. Perbedaan sikap tersebut muncul karena perbedaan persepsi, apakah bunga yang diberikan bank kepada nasabah atau sebaliknya adalah termasuk riba yang diharamkan atau tidak ?. Ada tiga pendapat yang populer dalam hal ini. (Hasan, 2000 : 41-42, Kasdi, 2011: 149-151 )

Pertama, pendapat yang membolehkan yang memandang bahwa bunga bank tidak masuk riba yang diharamkan. Ada beberapa alasan yang diajukan, antara lain: 1) bahwa riba yang dilarang adalah riba konsumtif sedangkan bunga bank adalah riba produktif. 2) bahwa riba yang dilarang adalah riba yang berlipat ganda sementara bunga bank tidaklah demikian. 3) bahwa adanya bank adalah suatu kebutuhan dalam rangka menghidupkan roda perekonomian negara. Maka umat Islam dengan demikian dalam keadaan darurat untuk berinteraksi dengan bank. Pendapat ini dilontarkan oleh Syeh Mushtofa Ahmad al-Zarqo, A. Hassan (Persis) dan Muhammad Hatta, wakil presiden pertama RI.

Pendapat kedua adalah pendapat yang mengharamkan bunga bank karena ia adalah riba yang jelas-jelas dilarang dalam Al-Qur'an dan Sunnah. Ia termasuk riba al-qordl sebab ia terjadi karena hutang piutang dan Al-Qur'an tidak membedakan antara yang sedikit maupun yang banyak, yang produktif maupun yang konsumtif. Alasan darurat sudah tidak relevan lagi setelah munculnya bank-bank yang tidak berbasis bunga. Pendapat ini adalah pendapat Syeh Muhammad Abu Zahroh, Abu Al-A'la al-Maududi, Syeh Yusuf al-Qorodhowi dan fatwa para Syeh Al-Azhar. Fatwa tentang haramnya bunga bank juga dikeluarkan oleh lembaga-lembaga fatwa resmi di dunia Islam, antara lain:

a. Konsul Kajian Islam dalam konferensi ke II yang diadakan di Universitas alAzhar Mesir Cairo pada bulan Mei 1965 M / Muharrom 1385 H yang dihadiri oleh sekitar 300 ulama besar dunia.

b. Sidang OKI (Organisasi Konferensi Islam) ke-2 yang diadakan di Karachi Pakistan pada bulan Desember 1970. Dalam siding ini ditetapkan dua hal : pertama, praktik bank dengan system bunga adalah tidak sesuai dengan syariah 
Islam. Kedua, perlu segera didirikan bank-bank alternative yang menjalankan operasionalnya sesuai dengan prinsip-prinsip syariah.

c. MUI (Majlis Ulama Indonesia) dalam fatwanya nomer 01 tahun 2004 setelah Ijtima' Ulama Komisi Fatwa se-Indonesia pada tanggal 16 Desember 2003 memfatwakan status hokum bunga bank konfensional.

Pendapat ketiga adalah yang mengatakan bahwa bunga bank adalah sesuatu yang masih syubhat. Artinya hukum bunga bank belum jelas kehalalannya dan keharamannya karena ia adalah sesuatu yang baru yang tidak secara jelas ada keterangannya dalam Al-Qur'an dan As-Sunnah. Pendapat ini adalah pendapat yang dipilih oleh Muhammadiyyah dan Nahdlatul Ulama.

Termasuk kelompok pertama yang memperbolehkan bunga bank adalah pemikir kontraversial asal Syria Prof. Dr. Ir. Muhammad Syahrur. Dalam masalah riba, Syahrur mempunyai pendapat unik yang tidak sama dengan pendapat sarjana-sarjana muslim lain. Ia mengkorelasikan antara riba dengan zakat setelah ia menemukan teori batas yang sangat mentakjubkan. Siapakah Muhammad Syahrur, bagaimana asal-usul teori batas yang ia gagas dan bagaimana pendapatnya tentang riba ?. Tulisan singkat dibawah ini akan mencoba menguraikannya.

\subsection{Biogafi Muhammad Syahrur}

Prof. DR. Ir. Muhammad Syahrur bin Daeb, adalah seorang cendekiawan asal Siria. Ia dilahirkan di Damaskus ibu kota Siria pada 11 April 1938. Pendidikan dasar dan menengahnya-Ibtidaiyyah, I'dadiyah, dan Tsanawiyah-ditempuh di kampung Al-Midan pinggiran kota sebelah selatan Damaskus. Ia menyelesaikan dan memperoleh ijasah dari Madrasah Abdur Rahman Al-Kawakibi tahun 1957. Pada tahun 1958 ia dikirim oleh pemerintah ke Uni Soviet untuk menempuh pendidikan teknik sipil di Moskow dan memperoleh ijasah diploma tahun 1964. Di Moskow Syahrur berjumpa dan berteman dengan Ja'far Dek Al-Bab yang kemudian banyak mempengaruhi pemikiran linguistiknya dan dianggap sebagai guru. Sekembalinya dari Moskow, Syahrur ditunjuk menjadi asisiten dosen dan mengajar pada Fakultas Teknik Sipil Universitas Damaskus. Tetapi tidak lama setelah mengajar di Universitas Damaskus, dia diutus oleh pihak Universitas untuk melanjutkan studinya ke Irlandia untuk menempuh program Magister dan Doktor bidang teknik sipil khususnya dalam hal pedologi dan agrologi (ada juga yang menyebut dengan soil mechanics dan foundation engineering) pada University College di Dubin. Pada waktu di Irlandia inilah Syahrur mulai serius mengkaji keIslaman dan menyusun buku yang kemudian hari sangat menghebohkan, yaitu al-Qur'an wa al-kitab; Qiroah $M u^{\prime} a s h a r a h$. Selesai dari studinya di Irlandia, Syahrur lalu diangkat menjadi Profesor jurusan teknik sipil di Universitas Damaskus dan mengajar mata kuliah mekanika pertahanan dan geologi. Ditilik dari backround pendidikannya, Syahrur sebenarnya bukan seorang ulama maupun pakar di bidang studi Islam seperti ilmu tafsir, fiqih maupun linguistik. Latar belakang studinya adalah teknik sipil (handasah 
madaniyah) dan teknik pertanahan (handasah al-turbah) dan bangunan. Meskipun begitu, Syahrur sering melibatkan dirinya dalam kajian keIslaman dan isu-isu liberalisasi syariat dan dekonstruksi tafsir Al-Quran. Beberapa hukum Islam dan kaedah Ilmu Tafsir pun dipertanyakan dan dirombak dengan berbekal Ilmu Teknik dan mengandalkan asal-usul ke-Arabannya. Ia juga pernah menjadi salah satu tenaga ahli pada Al-Saud Consult kerajaan Saudi Arabia tahun 1982-1983. (Ridwan, 2008: 43-44, Fanani (a), 2009: 31-34.

\subsection{Karya-karya Muhammad Syahrur.}

Muhammad Syahrur termasuk sarjana yang ulet dan produktif. Ia telah menulis beberapa buku yang berhubungan dengan tehnik sipil maupun studi keIslaman. Karyanya yang berhubungan dengan teknik adalah:

a.Handasah al-asasiyah (tiga jilid),

b. Handasah al-Turabiyah (satu jilid).

Sedangkan karyanya dibidang keIslaman adalah : (www. shahrour. org 20September-2015)

a.Al-Qur'an wal Kitab, Qira'ah Mu'ashirah (1990, 800 hlm ) yang ditulisnya selama 20 tahun.

b. Dirasat Islamiyah mu'ashirah fi al-dawlah wa al-mujtama (1994, $375 \mathrm{hlm})$.

c. Al-Islam wa Al-Iman: Manzumat Al-Qiyam. (1996, $400 \mathrm{hlm})$.

d. Nahwa Ushul jadidah lil-figh al-Islami $(2000,400 \mathrm{hlm})$.

e.Tajfif Manabi' al-Irhab (2008, 300 hal).

f.Masyru' Mitsaq Al-Amal Al-Islami. Sebuah buku yang sangat dikagumi kalangan liberal.

g. Al-Sunnah al-Rasuliyyah wa Al-Sunnnah al-Nabwiyyah.

h. Al-Qoshosh al-Qur, ani, Madkhol wa Qishshotu Adam.

i. Al-Qoshosh al-Qur, ani, Qiro'ah Mu'ashiroh.

j. Al-Din wa al-Sulthoh.

Di samping itu, Syahrur juga sering menyumbangkan buah-pikirannya lewat artikel-artikel dalam seminar atau media publikasi, seperti "The Divine Text and Pluralism in Muslim Societies", dalam, Muslim Politics Report, 14 (1997), dan "Islam and the 1995 Beijing World Conference on Woman", dalam, Kuwaiti Newspaper, dan kemudian dipublikasikan juga dalam, Charles Kurzman (ed. ), Liberal Islam, “ Proposal for Islamic Covenant", "Reading the Religious Text: A New Approach", "AlHarakah al-Libraliyyah Rafadhat al-Figh wa Tasyriatiha walakinnaha lam Tarfudh al-Islam ka tawhid wa Risalah Samawiyyah", dan " al-Harakah al-Islamiyyah lan Tafuz bi AsySyar, iyyah illa idza Tarahat Nadhriyyah Islamiyyah Mu, ashirah fi ad-Dawlah wa al-Mujtama'. " (Fanani (a), 2009: 43).

Untuk lebih mensosialisaikan pemikirannya, kini Syahrur membuka web. site sendiri dengan alamat www. shahrour. org. Dalam web. site nya ini ia menampilkan semua karya-karyanya, rekaman video ceramah dan seminarnya di 
berbagai negara sehingga dapat difahami dengan utuh pikiran-pikirannya. Yang menarik, ia juga menampilkan buku-buku yang mengkritik pikirannya. Hal ini dimaksudkan agar terjadi dialog konstruktif antara dia dan orang-orang yang mengkritiknya, sehingga menciptakan suasana chek and balance.

Pemikiran Syahrur mulai dikenal dan ramai diperbincangkan khalayak sejak dipublikasikanya buku Al-Kitab wa Al-Qur'an pada tahun 1990. Buku ini telah menimbulkan pro dan kontra di negara-negara Timur Tengah. Banyak tanggapan positif dan negatif dialamatkan kepadanya. Namun Syahrur tak bergeming dengan berbagai tanggapan itu, ia tetap menunjukkan sebagai seorang pemikir yang konsisten dan gigih.

Orang-orang yang kontra dengannya rata-rata datang dari kalangan tradisionalis konserfatif. Syahrur harus menghadapi berbagai kecaman bahkan juga ancaman dari mereka atas ide-idenya yang sangat orisinal dan berani. Sejak tahun 1990 sampai sekarang ini ia tengah menjadi objek kritikan di dunia arab. Tidak kurang dari 17 buku disamping makalah-makalah di berbagai majalah dan jurnal ditulis, untuk menyerang dan mengkritisi pemikirannya. Dalam pandangan pengkritiknya Syahrur sering dicap sebagai seorang murtad, kafir, setan, komunis, pencipta agama baru, dan sebagainya. Ia juga sering dituduh sebagai agen Barat dan Zionis. Hal itu masih ditambah lagi dengan larangan secara resmi beredarnya buku-buku Syahrur dari pemerintah negara-negara timur tengah, seperti Saudi Arabia, Mesir, Qatar dan Uni Emirat Arab. (Sahiron, 2002: 132-133, Fanani (a), 2009: 35). Berikut adalah beberapa buku yang mengkritik tajam pemikiran-pemikiran Syahrur :

a. Al-Qiroah al-Muashirah li al-Duktur Syahrur - Mujarrodu al-Tanjim (Salim alJabi, 1991).

b. Tahāfut al-Qirāah al-Mu'āşirah (Munīr Muhamad Thāhir al-Shawwāf, Limasoul, al-Shawwāf li al-Nashr wa al-Dirāsah, 1993) ;

c. Al-Qurān wa Awhām al-Qirāah al-Mu'āşirah (Jawwād 'Affānah, Amman, Dar al-Bashīr, 1994)

d. Al-Qirāah al-Mu'āşirah fì al-Mīzān, Al-MarkIslamiyah wa al-Qur'an (Muhamad Soyyāh al-Ma'arawy, Beirut-Damaskus-Aman, al-Maktab alIslāmy, 2000)

e. Al-Tahrīf al-Mu'āshir fì al-Dìn ('Abd al-Rahmān ibn Hasan Habannakah alMaydāni, Damaskus, Dār al-Qalam, 1997).

f. Al-Furqan wa al-Qur'an - Qira'ah Islamiyyah Mu'ashirah Dhimna al-Tsawabiy al-'Amiyyah wa al-Dhawabith al-Manhajiyyah - 1994, (Al-Syaikh Khalid Abdurrahman al-'Akk)

g. Al-Qira'ah al-Mu'ashirah li al-Qur'an fi al-Mizan, 1995, (Ahmad Imran).

h. Tahafut al-Dirasah al-Mu'ashirah fi al-Daulah al-Mujtama', 1995, (Munir Muhammad Thahir al-Syawwaf. 
i. Baidlatu al-Dik - Naqdun Lughawiy li Kitab "al-Kitab wa al-Qur'an", 1993, Yusuf al-Shaidawiy

j. Qira'ah 'ilmiyyah li al-Qira'at al-Mu'ashirah, 1990, Dr. Syauqi Abu Khalil.

k. Dan lain-lain.

Sedangkan dukungan dan apresiasi kepada Syahrur datang dari kalangan modernis-liberal. Sarjana-sarjana non-Muslim seperti Wael B. Hallaq dan Dale F. Eickelman dalam kesempatan yang berbeda mengemukakan kekaguman mereka terhadap kreatifitas dan pemikiran Syahrur. Dari kalangn pemerintahan barangkali hanya Sultan Qobus dari Oman satu-satunya pemerintahan di Arab yang mendukung Syahrur, sehingga ia membagi-bagikan buku Syahrur kepada para menterinya dan merekomendasikan mereka untuk membacanya. (Sahiron, 2002: 133). Sarjana-sarjana Indonesia juga banyak yang memberikan apresiasi dan mengagumi Syahrur. Dr. Muhyar Fanani yang menulis disertasinya tentang Syahrur memberikan pujian dan komentar atas pemikiran Syahrur : " Perlu dicatat bahwa dari sekian pemikir usul fikih liberal itu, Syahrur memiliki sumbangan yang paling meyakinkan...Syahrur mampu menawarkan perangkat analisis tekstualkontekstual yang terstruktur sehingga lebih mungkin melahirkan hukum yang humanistik tapi secara umum masih dituntun oleh maksud wahyu" (Fanani (b), 2010 : 190).

Nampaknya Syahrur tidak memiliki jaringan yang kuat, baik di pemerintahan maupun LSM, ormas atau lembaga akademik, sehingga ia harus berjuang sendiri dari kantor kecilnya di perempatan Muhajirin Damaskus. Syahrur hanya mengandalkan dukungan dari sejumlah kecil pribadi dan sokongan tak resmi dari pemerintah Syiria yang tidak menginginkan terulangnya kasus Fazlurrahman di Pakistan dan Nashr Hamid Abu Zayd di Mesir yang diusir dari negara mereka.

\subsection{Teori Batas Muhammad Syahrur}

Ilmu fiqh yang banyak dipegangi oleh umat Islam sampai sekarang, Muhammad Syahrur berpendapat bahwa produk-produk fiqh yang ada sekarang (al-fuqaha`al-khamsah) sudah tidak relevan lagi dengan tuntutan modernitas. Yang diperlukan adalah formulasi fiqh baru (Syahrur, 1990: 567 ). Kegelisahan Syahrur semacam ini sebetulnya sudah muncul dari para kritikus fiqh. Tapi, umumnya hanya berhenti pada kritik tanpa menawarkan alternatif baru.

Di tempat lain, Syahrur mengatakan, kajian-kajian keIslaman yang ada sering melupakan dimensi universalitas Syariat Islam yang shalih li kull zaman wa makan. Indikasinya, konstruksi fiqh selalu berada pada posisi keberpihakan; bahwa saya sajalah yang paling benar. Formulasi fiqh seperti ini menghalangi umat Islam sendiri dari prinsip dasar syariah, yaitu bahwa Rasul Muhammad adalah Rasul untuk semua manusia, dan risalahnya tetap layak dan relevan untuk segala zaman dan tempat. Karakter fiqh yang sering dilupakan oleh para fuqoha menurut Syahrur adalah hanifiyyah (elastisitas, perubahan). (Syahrur, $1990: 616$ ) 
Syahrur sangat bersikeras bahwa tiap-tiap generasi mampu memberikan interpretasi al-Qur`an yang memancar dari realitas yang muncul dan sesuai dengan kondisi di mana mereka hidup. Hasil interpretasi al-Qur`an generasi awal tidaklah mengikat masyarakat Muslim modern. Bahkan lebih jauh, kesalahan utama fiqh Islam dan tafsir al-Qur’an konvensional sekarang ini bersumber dari kesalahan metodologi yang tidak memperhatikan karakteristik dan fleksibilitas pengertian teks-teks Kitab Suci, sehingga membebani punggung umat dan tidak sesuai lagi dengan kemajuan ilmu pengetahuan serta situasi dan kondisi abad ke-20. (Syahrur, 1990: 132 )

Oleh karena itu, Syahrur ingin melakukan dekonstruksi besar-besaran terhadap rancang bangun fiqh Islam yang telah dianggap mapan selama berabadabad. Dari sekian banyak dekonstruksi Syahrur terhadap turost yang diwariskan oleh ulama-ulama masa lalu, barangkali teori limit (nadhoriyyat al-hudud) adalah temuan Syahrur yang paling original dan kontraversial.

Teori limit ini ia temukan setelah menemukan dua kata dalam Al-Qur, an yang membuatnya gelisah dan penasaran. Dua kata itu adalah al-hanif (condong, bengkok, melengkung) dan al-mustaqim (lurus, tegak, kuat ) yang secara lahir mempunyai makna yang berlawanan ketika dijadikan sifat dari agama Islam. Bagaimana mungkin Islam menjadi kuat disusun dari dua hal yang kontradiksi ?.

Setelah melakukan analisis linguistik sebagaimana metode yang telah ia tetapkan, Syahrur berkesimpulan bahwa kedua kata itu tidak kontradiksi tapi mempunyai makna yang harmonis. Al-Hunafa adalah sifat alami dari seluruh alam yang meliputi langit dan bumi sebagai susunan kosmos. Ia bergerak dalam garis lengkung, bahkan elektron terkecil pun juga demikian. Tidak ada dari tata alam itu yang tidak bergerak melengkung. Sifat inilah yang menjadikan tata kosmos itu menjadi teratur dan dinamis. Al-din al-hanif, dengan demikian dapat dipahami agama yang selaras dengan kondisi ini, karena al-hanif merupakan pembawaan yang bersifat fitriyyah. Manusia sebagai bagian dari alam materi ini, juga memiliki sifat pembawaan fitriyyah ini. (Syahrur, 1990: 449).

Secara ringkas teori hudud yang digagas oleh Syahrur adalah, " teori yang menyatakan bahwa Allah hanya memberikan batasan-batasan saja dalam persoalan hukum dan manusia bebas menciptakan hukum sesuai dengan nalarnya dengan tanpa melanggar batas-batas yang telah ditentukan oleh Allah". (Fanani (a), 2007: xxxi).

\subsection{Riba dan Zakat}

Ada enam model teori batas yang dikemukakan Syahrur, sebagaimana berikut: (Syahrur (a), 1990: 453-468, Fanani, 2007: 257)

a. Batas minimal. (berlaku pada masalah : pihak perempuan yg haram dinikahi (maharim al-nikah), jenis makanan yang dilarang dikonsomsi, 
hutang piutang, pakaian perempuan, hukuman pembunuhan tersalah).

b. Batas maksimal. (berlaku pada masalah: hukuman potong tangan bagi pencuri dan hukuman qishos bagi pembunuh dengan sengaja ).

c. Batas minimal dan maksimal bersamaan tetapi tidak menyatu dalam satu titik atau satu garis. (berlaku pada masalah poligami dan pembagian warisan).

d. Batas minimal dan maksimal bersamaan pada satu titik atau posisi lurus atau posisi penetapan hukum partikular (Ainiyah). (berlaku pada masalah hukuman bagi pelaku zina)

e. Batas maksimum dengan satu titik mendekati garis lurus tanpa persentuhan. (berlaku pada masalah hubungan fisik antar lawan jenis)

f. Batas maksimum "positif" tidak boleh dilewati dan batas bawah " negative" boleh dilewati. (berlaku pada masalah distribusi harta kekayaan, riba-" batas maksimal posisi positif ", zakat- " batas minimal posisi negative", sedekah ).

Dari beberapa model teori batas diatas dapat kita fahami bahwa pandangan Muhammad Syahrur tentang riba dan zakat termuat pada teori batas yang keenam yaitu " batas maksimal (positif) tidak boleh di lewati dan batas bawah (negatif) boleh di lewati". Batasan ini berlaku pada hubungan peralihan harta kekayaan antar manusia. Dua batas ini terdiri dari batas maksimal yang tidak boleh dilanggar, yaitu riba dan batas minimal berupa zakat yang dapat dilampaui. Bentuk melampaui batas minimal ini berupa berbagai macam sedekah. Dua batas ini terdapat pada dua daerah yaitu daerah positif dan daerah negatif, dan titik tengah pada posisi netral yang dilambangkan dengan nol. Pada dataran aplikasi, batas maksimal positif berupa riba, batas netral berupa pinjaman tanpa bunga dan pada batas minimal negatif berupa zakat dan sedekah. (Syahrur, 1990: 465-466).

Syahrur membahas riba dalam kitabnya Al-Kitab wal Al-Qur, an hanya dalam lima halaman yaitu mulai halaman 467-471. Dalam paragraph pertama ia berkata : " Telah saya katakana bahwa topic tentang riba adalah termasuk hudud Allah nomer enam yaitu batas maksimal positif, netral atau nol dan batas minimal negative. Oleh karena itu topic tentang riba tidak bisa dipisahkan dengan topic tentang zakat dan sedekah". Setelah itu Syahrur menerangkan tentang makna riba secara bahasa yang berarti al-ziyadah (bertambah), al-nama' (berkembang) dan al'uluw (tinggi). Lantas menyebutkan ayat-ayat dalam Al-Qur, an yang membahas tentang riba yaitu: 


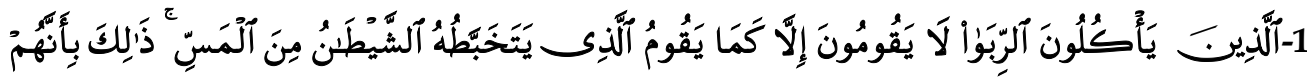
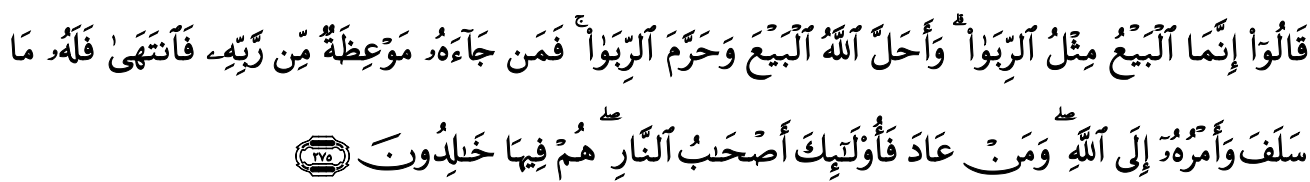

“ Orang-orang yang Makan (mengambil) riba tidak dapat berdiri melainkan seperti berdirinya orang yang kemasukan syaitan lantaran (tekanan) penyakit gila. Keadaan mereka yang demikian itu, adalah disebabkan mereka berkata (berpendapat), Sesungguhnya jual beli itu sama dengan riba, Padahal Allah telah menghalalkan jual beli dan mengharamkan riba. orang-orang yang telah sampai kepadanya larangan dari Tuhannya, lalu terus berhenti (dari mengambil riba), Maka baginya apa yang telah diambilnya dahulu (sebelum datang larangan); dan urusannya (terserah) kepada Allah. orang yang kembali (mengambil riba), Maka orang itu adalah penghuni-penghuni neraka; mereka kekal di dalamnya'. (QS AlBaqoroh : 275).

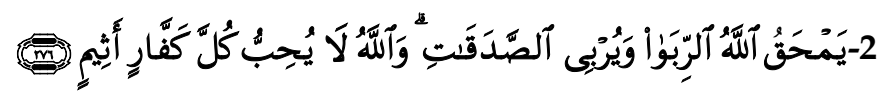

"Allah memusnahkan Riba dan menyuburkan sedekah. dan Allah tidak menyukai Setiap orang yang tetap dalam kekafiran, dan selalu berbuat dosa ". (QS Al-Baqoroh: 276)

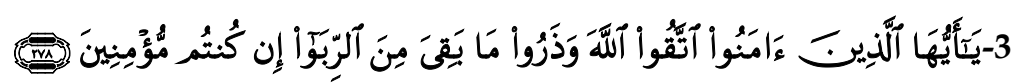

"Hai orang-orang yang beriman, bertakwalah kepada Allah dan tinggalkan sisa Riba (yang belum dipungut) jika kamu orang-orang yang beriman." (Al-Baqoroh : 278).

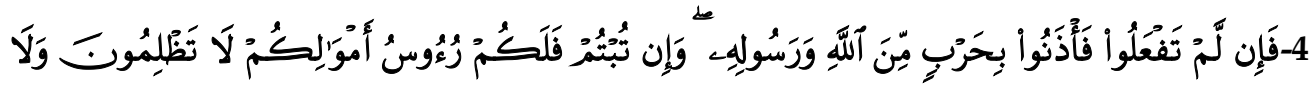

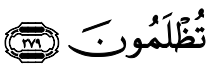

"Maka jika kamu tidak mengerjakan (meninggalkan sisa riba), Maka ketahuilah, bahwa Allah dan Rasul-Nya akan memerangimu. dan jika kamu bertaubat (dari pengambilan riba), Maka bagimu pokok hartamu; kamu tidak Menganiaya dan tidak (pula) dianiaya. (AlBaqoroh : 279)

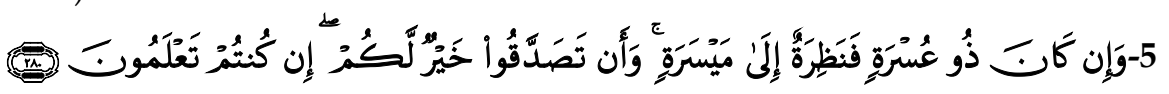

"Dan jika (orang yang berhutang itu) dalam kesukaran, Maka berilah tangguh sampai Dia berkelapangan. dan menyedekahkan (sebagian atau semua utang) itu, lebih baik bagimu, jika kamu mengetahui ". (Al-Baqoroh : 280)

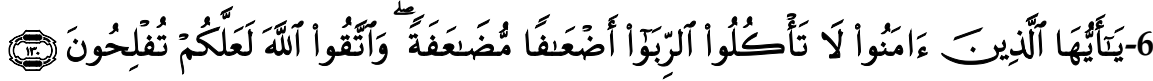

"Hai orang-orang yang beriman, janganlah kamu memakan Riba dengan berlipat ganda[228]] dan bertakwalah kamu kepada Allah supaya kamu mendapat keberuntungan'. (QS Ali Imron : 130). 


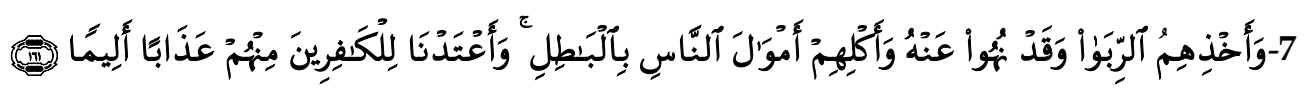

“Dan disebabkan mereka memakan riba, Padahal Sesungguhnya mereka telah dilarang daripadanya, dan karena mereka memakan harta benda orang dengan jalan yang batil. Kami telah menyediakan untuk orang-orang yang kafir di antara mereka itu siksa yang pedih". (QS Al-Nisa: 161)

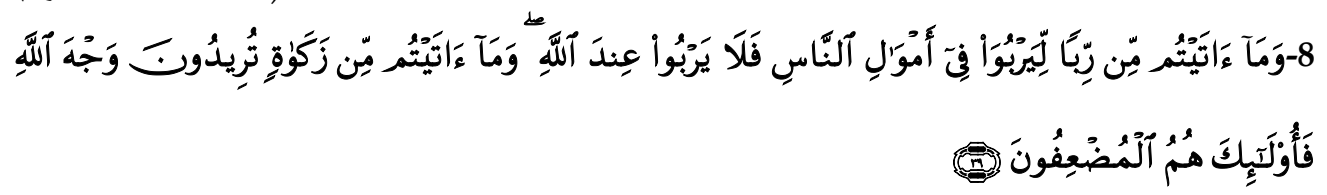

“Dan sesuatu Riba (tambahan) yang kamu berikan agar Dia bertambah pada harta manusia, Maka Riba itu tidak menambah pada sisi Allah. dan apa yang kamu berikan berupa zakat yang kamu maksudkan untuk mencapai keridhaan Allah, Maka (yang berbuat demikian) Itulah orang-orang yang melipat gandakan (pahalanya). (QS Ar-Rum: 39).

Ada beberapa kesimpulan yang ditarik oleh Syahrur dari ayat-ayat itu antara lain:

a. Menghubungkan riba dengan sedekah dalam QS. Al-Baqoroh : 276.

b. Menghubungkan riba dengan zakat dalam QS. Ar-Rum : 39.

c. Meletakkan batas maksimal untuk bunga riba dalam QS. Ali Imron: 130.

d. Meletakkan batas nol dalam QS. Al-Baqoroh: 279.

Setelah menukil ucapan Umar bin Khottob RA tentang tiga hal yang sulit sebagaimana dikutip oleh Ibnu Katsir ketika menfsirkan ayat kalalah, Syahrur berkesimpulan bahwa riba adalah masalah yang tidak pasti, sampai Amirul Mukminin Umar RA merasa kesulitan.

Bagaimana hubungan riba, zakat dan shodaqoh ?. Menurut Syahrur zakat dan shodaqoh adalah sejumlah uang atau barang yang diberikan seseorang kepada orang lain dengan tanpa adanya ganti atau ikatan antara pemberi dan penerima. Bedanya anatara zakat dan shodaqoh adalah khusus dan umum. Istilah shodaqoh itu umum yang memasukkan zakat didalamnya, hanya saja zakat adalah batas minimal hibah yang wajib dilakukan dalam Islam. Dengan demikian zakat dan shodaqoh adalah wilayah yang terbuka baik secara kuantitas maupun kualiatasnya. Ia terbuka untuk dilakukan ijtihad dalam ukurannya bisa ditambah atau dikurangi sesuai dengan keadaan ekonomi dan kebutuhan masyarakat. Artinya, menurut Syahrur tidak ada nishob tertentu dan tarif zakat tertentu, sebab semua itu disesuaikan dengan situasi dan kondisi. Nishob-nishob dan tarif zakat yang wajib dikelurkan sebagaimana telah ditentukan Rasulullah SAW tidaklah wajib diikuti, sebab Rasulullah menurut Syahrur hanyalah sebagai mujtahid pertama yang hasil ijtihadnya hanya cocok pada masanya dan wilayahnya. Sikap Syahrur terhadap Sunnah ia jelaskan sebagai berikut : "Sunnah adalah ijtihad pertama, pilihan pertama bagi bingkai penerapan yang dipilih oleh Nabi SAW, untuk membumikan 
pemikiran mutlak yang diwahyukan kealam nyata...sunnah nabi bukanlah yang terakhir dan satu-satunya, artinya sunnah nabi adalah penerapan pertama bagi realitas kehidupan. Sunnah nabi cermin terpercaya pertama yang melukiskan interaksi antara at-Tanzil al-Hakim dan dunia objektif, yang menjalankan isi atTanzil al-Hakim dengan segala dimensinya yang hakiki tanpa ada keraguan dan khayalan". (Syahrur, 2000: 63). Al-Sunnah bukanlah pembicaraan yang konkret atau spesifik dari Nabi, melainkan merupakan metode dalam berinteraksi dengan alKitab sesuai dengan realitas objektif yang dijumpai oleh Nabi. Dengan sunnah inilah nabi menjadi uswah hasanah bagi kita".

Dari ayat-ayat Allah yang berkaitan dengan riba, zakat dan sedekah, Syahrur mengelompokkan kondisi seseorang dilihat dari kepemilikan hartanya sebagai berikut : (Syahrur, 1990: 467-471)

1) Kelompok yang tidak memiliki kemampuan melakukan transaksi bentuk apapun. Kelompok seperti ini berhak menerima harta dalam bentuk pemberian, bukan pinjaman. Yang termasuk dalam kategori ini adalah golongan yang wajib menerima zakat yaitu orang yang tidak mampu melakukan transaksi ekonomi apapun, atau tidak mampu melunasi bentuk pinjaman harta selunak apapun dalam sistem perekonomian yaitu kelompok fuqoro dan masakin. Untuk kelompok ini berlaku ayat Allah: QS Al-Baqoroh: 276

$$
\text { يمحق الله الربا ويربى الصدقات }
$$

"Allah memusnahkan riba dan menyuburkan sedekah", dan firman Allah QS Ar-Rum: 39.

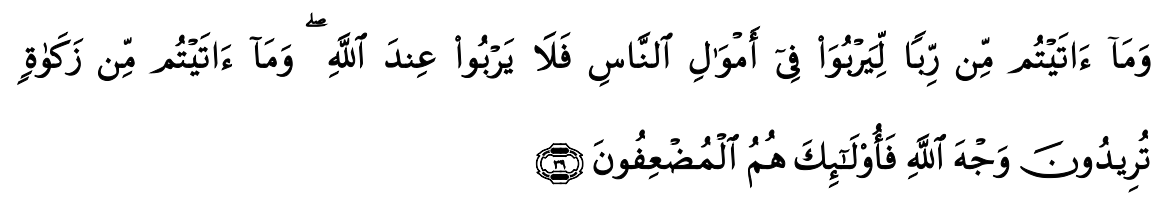

“Dan sesuatu Riba (tambahan) yang kamu berikan agar Dia bertambah pada harta manusia, Maka Riba itu tidak menambah pada sisi Allah. dan apa yang kamu berikan berupa zakat yang kamu maksudkan untuk mencapai keridhaan Allah, Maka (yang berbuat demikian) Itulah orang-orang yang melipat gandakan (pahalanya). (QS Ar-Rum: 39).

2) Kelompok orang-orang yang mampu mengembalikan pinjaman tapi tanpa bunga sama sekali. Bentuk ini berupa pinjaman yang bernilai netral atau disebut dengan pinjaman qardul hasan yaitu pinjaman tanpa bunga. Kondisi ini dijelaskan dalam surat al-Baqarah: 279 ; 


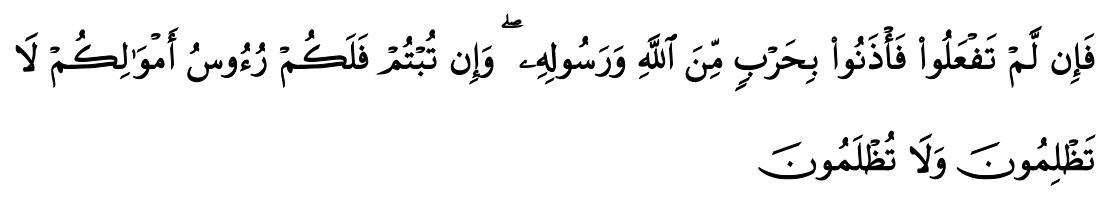

"Maka jika kamu tidak mengerjakan (meninggalkan sisa riba), Maka ketahuilah, bahwa Allah dan Rasul-Nya akan memerangimu. dan jika kamu bertaubat (dari pengambilan riba), Maka bagimu pokok hartamu; kamu tidak Menganiaya dan tidak (pula) dianiaya".

Kelompok kedua seperti ini model pengalihan hartanya harus mengikuti teori batas maksimal yang hanya boleh diterapkan pada mereka. Oleh karenanya, Allah menganjurkan pemberian bukan pinjaman, yaitu dengan firman-Nya dalam surat al-Baqarah: 280 .

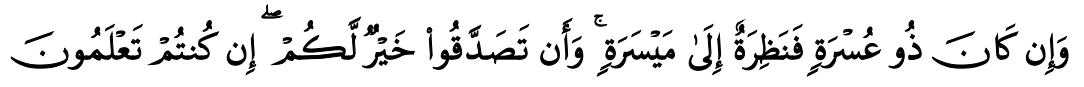

“Dan jika (orang yang berhutang itu) dalam kesukaran, Maka berilah tangguh sampai Dia berkelapangan. dan menyedekahkan (sebagian atau semua utang) itu, lebih baik bagimu, jika kamu mengetahui".

3) Kelompok manusia yang tidak berhak menerima pemberlakuan ayat-ayat sedekah, dan zakat. Mereka adalah kelompok manusia yang memperoleh penghasilan besar dari mata pencahariannya, seperti konglomerat di sektor perniagaan, industri, agrobisnis. Termasuk kategori ini adalah mereka yang menduduki posisi penting dalam jasa transportasi, komunikasi, perusahaan pertambangan, dan bentuk-bentuk usaha yang lainnya. Dan untuk kelompok ini berlaku posisi batas maksimal pengambilan keuntungan bunga sebagaimana firman Allah surat Ali Imron: 130.

Menurut Syahrur riba dibagi dalam dua bentuk yakni yang berkaitan dengan pinjam meminjam dan jual beli. Syahrur berpendapat bahwa riba sama dengan bunga bank dan ia menghalalkan bunga bank seperti mekanisme perbankan modern yang telah dijalankan selama ini. Hanya saja menurut Syahrur sesuai dengan apa yang telah dia jelaskan diatas, mekanisme perbankkan seharusnya dijalankan sebagaimana berikut :

1. Mekanisme zakat dan shodaqoh murni. Mekanisme ini diberikan kepada golongan yang berhak menerima zakat dan shodaqoh sehingga pinjaman tidak boleh diterapkan pada mereka. Pengalihan harta kepada kelompok ini melalui mekanisme shodaqoh dan zakat yaitu berupa pemberian murni tanpa syarat apapun.

2. Mekanisme alqordlalhasan. Yakni bila kelompok manusia dalam kondisi tertentu mekanisme maksimal yang boleh diterapkan kepada kelompok yang berhak menerima sedekah adalah pinjaman tanpa bunga (alqardlualhasan). 
3. Bila bank Islam ingin memberikan pinjaman kepada masyarakat maka masyarakat yang diperbolehkan menerima adalah masyarakat kelompok ketiga yaitu kelompok yang berpenghasilan besar. Namun pinjaman yang diberikan oleh perbankan Islam tidak diperkenankan memberikan beban bunga melebihi dua kali lipat (100\%) dari modal pinjaman untuk jangka waktu yang tak terbatas. Menurut Syahrur bunga pinjaman 100\% merupakan batas maksimal yang boleh diterapkan dalam sistem perbankkan Islam.

Alasan mengapa mustahiq zakat tidak boleh diberi pinjaman dengan bunga karena ketika fuqoro' dan masakin dipungut riba atau bunga mereka akan merasa teraniaya. Karena mereka meminjam digunakan untuk konsumtif semata atau pemenuhan hidup yang ia butuhkan. Jadi menurut Syahrur, bagi fuqoro', masakin, atau yang berhak menerima zakat dan sedekah tidak boleh di pungut riba melainkan bagi mereka hanya diberikan pinjaman dengan mengembalikan pokok pinjamannya saja, dan bahkan ketika benar-benar tidak mampu untuk mengembalikan pokok pinjamannya mereka berhak untuk menerima pemberian atau hibah dengan tanpa syarat. Pada mekanisme ketiga yaitu memberi pinjaman kepada orang yang mampu maka pinjaman tersebut berupa pinjaman produktif. Karena pada pinjaman produktif tersebut tidak ada yang teraniaya akan tetapi menguntungkan kedua belah pihak. karena pada dasarnya pihak yang meminjamkan / perbankkan sebagai pemilik modal yang tidak menjalankan usaha dan peminjam merupakan orang yang mempunyai skill untuk menjalankan usaha.

Dari uraian diatas secara singkat dapat disimpulkan bahwa ketika pinjaman tersebut untuk kepentingan produktif, Syahrur memperbolehkan pemungutan tambahan/riba dengan batas maksimal pemungutan adalah $100 \%$ dari pokok pinjaman. Dan ketika pinjaman itu untuk konsumtif, Syahrur tidak memperbolehkan pemungutan tambahan / riba tetapi dengan mekanisme alqordlalhasan atau bahkan dengan mekanisme zakat atau sedekah.

\section{PENUTUP}

Ada beberapa catatan atas pemikiran Syahrur tentang konsep riba dan zakat diatas. Pertama, Syahrur nampaknya terlalu tunduk dengan realitas yang ada yaitu system ekonomi kapitalis dimana perbankkan yang didasarkan pada sistem riba merupakan jantungnya, tanpa memikirkan akibat yang ditimbulkan dari sistem itu. Telah banyak kajian dan laporan dari para pakar ekonomi yang menginformasikan dampak negative dari system bunga ini baik dari sisi personal, social maupun ekonomi. Dampak negative system bunga terhadap ekonomi adalah: (Kasdi, 2011: 156) " adanya inflasi yang diakibatkan oleh bunga sebagai biaya uang. Hal tersebut disebabkan karena salah satu elemen dan penentuan harga adalah suku bunga. Semakin tinggi suku bunga semakin tinggi juga harga yang akan ditetapkan pada suatu barang. Dampak lainnya adalah bahwa hutang dengan rendahnya tingkat 
penerimaan peminjam dan tinnginya biaya bungaakan menjadikan peminjam tidak pernah keluar dari ketergantungan, terlebih lagi bila bunga atas hutang tersebut dibungakan. Contoh paling nyata atas akibat dari system bunga ini adalah hutang negara-negara berkembang kepada negara-negara maju ". Data-data tentang hal ini sudah banyak dipublikasikan. Syahrur seharusnya bersikap kritis atas realitas ini. Sikap tunduk pada realitas seperti ini memang banyak menimpa sarjana-sarjana muslim kontemporer.

Kedua, pendapat yang menyatakan bahwa riba diperbolehkan untuk pinjaman produktif dan tidak diperbolehkan untuk pinjaman konsumtif didasarkan pada asumsi bahwa setiap usaha bisnis pasti akan mendapatkan keuntungan tanpa memikirkan kemungkinan adanya resiko kerugian. Kita semua tahu bahwa kita tidak bisa memastikan apa yang akan terjadi pada masa yang akan datang. Setiap usaha manusia mempunyai dua kemungkinan, berhasil atau gagal. Dengan menetapkan riba atau tambahan pada setiap usaha bisnis berarti orang sudah memastikan bahwa usaha yang dikelola pasti untung, atau dipaksa untuk beruntung. Memastikan adanya keuntungan pada setiap usaha bisnis seperti ini disamping tidak realistis juga akan menimbulkan kedhaliman karena peminjam tetap harus memberikan bunga kepada pemilik modal atau bank meskipun peminjam merugi atau bahkan mengalami kebangkrutan. Tindakan seperti ini adalah tidak adil.

Ketiga, penetapan bunga yang ditolerir sampai $100 \%$ nampaknya bertentangan dengan perintah Allah SWT : "Dan tinggalkanlah apa yang tersisa dari riba bila kalian adalah orang-orang yang beriman". Ayat ini jelas melarang adanya riba meskipun hanya sedikit. Lantas dari manakah Syahrur menyimpulkan pendapatnya itu ? Bila dari kata adlafan mudloafah yang berarti berlipat-lipat bukan berlipat ganda, maka tidak hanya $100 \%$ sebagai batas maksimal tetapi bisa lebih dari itu.

Keempat, konsep riba yang ditawarkan Syahrur nampaknya tidak memberikan solusi atas problem system perbankkan yang selama ini berjalan tetapi hanya mencarikan legalitas atas apa yang terjadi. Syahrur tidak menyinggung system perbankkan yang didasarkan pada system bagi hasil sebagai bahan pertimbangan.

Kelima, mengkaitkan riba dengan zakat nampaknya terlalu dipaksakan hanya untuk memberikan justifikasi adanya teori batas yang ia ada-adakan. Ayat yang menyebutkan riba dan zakat atau shodaqoh seperti ayat 276 surat Al-Baqoroh dan ayat 39 surat Ar-Rum tidaklah mengkaitkan antara keduanya tetapi memberikan gambaran kontras antara keduanya. Karena banyak orang yang berkeyakinan bahwa pinjaman dengan system riba akan dapat membantu ekonomi masyarakat yang pada gilirannya akan meningkatkan pertumbuhan ekonomi, maka keyakinan seperti ini dibantah oleh Al-Qur, an dengan dua ayat tersebut. Kedua ayat tersebut ingin menyampaikan pesan, bahwa pinjaman dengan system bunga (riba) tidak 
akan membawa pertumbuhan dan perbaikan ekonomi masyarakat tetapi malah sebaliknya. Berbeda dengan system zakat yang dikelola dengan baik karena Allah SWT, maka ia akan membawa dampak yang positif terhadap perekonomian masyarakat. Jadi pemahaman Syahrur yang meletakkan kedua ayat itu pada kelompok masyarakat yang tidak memiliki kemampuan melakukan transaksi bentuk apapun sehingga mereka harus diberi zakat dan tidak boleh menerima pinjaman apapun adalah pemahaman yang jauh dari kontek.

Disamping itu, pendapat Syahrur ini agak janggal sebab seolah-olah orang yang berhak menerima zakat terbatas pada fuqoro dan masakin saja. Padahal AlQur, an sebagai mana disebutkan dalam QS. At-Taubah : 10 ada delapan golongan yang berhak menerima zakat. Salah satu golongan yang berhak menerima zakat itu adalah Amil (pengelola zakat) dan Sabilillah (orang yang berjuang di jalan Allah ). Apakah mereka juga orang yang tidak diperbolehkan menerima pinjaman apapun dari bank? Apakah mereka juga tidak diperbolehkan menerima pinjaman dengan mekanisme al-qordl al-hasan tanpa ada bunganya ? Bila mereka berdua adalah orang yang kaya, haruskah mereka bila menerima pinjaman harus dengan menggunakan mekanisme riba?.

\section{DAFTAR PUSTAKA}

Al-Kaf, Hasan bin Ahmad bin Muhammad, At-Taqrirot al-Sadidah fi al-Masail alMufidah, Riyadh, Dar al-Mirost al-Nabawi 2013

Fanani, Muhyar Dr, Figh Madani Konstruksi Hukum Islam di Dunia Modern, Yogyakarta LKiS 2009

Hasan, M. Ali, Masail Fiqhiyyah : Zakat, Pajak, Asuransi dan Lembaga Keuangan, Jakarta, PT Raja Grafindo Persada 2003

Ilahiy, Fadl Dr, At-Tadabir al-Waqiyah min al-Riba fi al-Islam, Jujralwala Pakistan, Idaroh Turjuman al-Islam, 1986 M / 1406 H

Kasdi, Abdurrahman. Masail Fiqhiyyah, Kajian Fiqh atas Masalah-masalah Kontempore, Nora Media Enterprise Kudus, 2011 M

Ridwan, MA, g, Limitasi Hukuim Pidana Islam, Semarang, Walisongo Press Cet, I September 2008.

Sahiron, Syamsuddin, Metode Intertekstualitas Muhammada Syahrur dalam Penafsiran Al-qur, an dalam Studi Al-Qur, an Kontemporer Ygyakarta Tara Wacana 2002.

Syahrur, Muhammad, Al-Kitab wa al-Qur'an: Qira'ah Mu'asirah, Damaskus: Al-Ahaly, 1990. Nahwa Usul jadidah li al-Figh al-Islami, Damaskus: Al-Ahaly, 2000. 